\title{
Determinant Factors of Successful Public Open Space in India
}

\author{
Adiba Shafique* and Roshida Abdul Majid \\ Faculty of Built Environment, Universiti Teknologi Malaysia, Johor Bahru, Malaysia
}

\begin{abstract}
The public open spaces are the inevitable part of the cities. These spaces act as a focal point which reflects the culture and the public life. There are in-numerous cities which are known for their public life while many are still struggling to satisfy their users need. This difference could be due the local significance and the context of the city. Therefore, the research paper will identify the factors of public open space in Indian context. The research paper has employed qualitative as well as quantitative methodology which is performed through literature review followed by questionnaire survey. Three different Public open spaces of New Delhi, India including New Friends colony, Saket, Nehru Place has been taken as site study over which questionnaire survey has been performed. The questionnaire design is based on the 'Likert scale' ranging from 1 to 5 i.e. from 'strongly disagree' to 'strongly agree'. The factors have been derived through literature review which is further analysed through questionnaire results. Each factor is divided into different construct having three to four questions which is analysed through Cronbach's alpha in order to evaluate the authenticity of response by users. Further, exploratory factor analysis using IBM SPSS software has been employed to explore the factors of Public open space in Indian context. The factors are further confirmed through confirmatory factor analysis using Amos software. The research findings show the significant factors namely, access and linkages, uses and activities, urban elements/Amenities, visual image and identity, maintenance and management and microclimate are the major factors of public open spaces in India.
\end{abstract}

Keywords: Public open space factors, Indian City context, Indian socio-cultural

\section{Introduction}

Public open spaces are one of the vital components of the cities as it reflects the culture. A Public open space is an area where people can sit, relax, interact and experience the public life of a city. It has been mentioned by various researchers that context has an immense impact on the factors that makes space effective. Moreover, in order to make Indian Public open spaces more effective, factors of Public open space have been examined in order to check their importance in Indian context. Thus, the aim of the research paper is to analyse the factors which contribute to make Public open space successful in Indian context. The outcomes of the research will enhance better understanding regarding successful factors of Public open space for Indian cities which eventually further helps in developing new theories on public open space. The objectives of the research will be achieved through conducting case studies which will be undertaken in three different public open spaces of New Delhi. The survey will be unfolded in two steps: observations leading to questionnaire which will be further assessed by exploratory factor analysis and confirmatory factor analysis.

\section{Literature Review}

\section{Public open space}

Debra Efroymson (2009) define public open space as a place where anyone can enter or leave without anyone's consent. The place gives the opportunity to interact, sit alone or in groups and observe people. It is a place where people can experience public life. A public open space is one of the vital elements of the city, which has a great impact on social, cultural, economic and environmental aspects of the city (Truong, 2008). Hume (2009) 
defines public open space is a place for community interaction, public protection, the pleasure of social life and values which is intend to planned and managed for present and future generations.

Sucker (2010) describes public open space as a reflection of socio-cultural as well as the political situation of society. Historically, cities have been depicted by the activities happened in public open spaces and considered a place for building communities. Hence, plays an essential role in fostering societies (Giddings et al., 2011). Adding to this Truong (2008) states that, earlier, public open space is considered as a central meeting place for political and societal decisions and a place for performing various individual or group activities. According to (Jan Gehl, 2003, p.10),

"Public open space is traditionally used as a marketplace, traffic space, performing socio-cultural activities and meeting place in balance, in spite of the different usage patterns of the city. Public space is a place where people can meet and make contact with each, exchange information, such as working experience or economic development. In addition, a lot of vital activities occur in public open space: the celebration of festivals, sociocultural activities, pageant, coronations, etc".

Kostof (1992) before car invention took place, public spaces were considered as one of the vital components of the city. In Greek civilisation 'agora - the marketplace,' showcases the pedestrian-oriented culture of the society while in roman, forums were the place for organising public affairs. Many historical public squares are still able to generate a sense of belonging and sense of place through demonstrating a socio-cultural of that society, hence, witnesses the public functions, festivals, day to day interactions between people and able to hold public for a longer time (Kostof, 1992).

Ancell and Thompson-Fawcett (2008) Hajjari (2009) elucidate that public open space are accessible to the public which creates livelihood in society with the help of effective cultural and physical settings. Cafes, retails, bazaars, streets, walkways, parks, etc. are included in public open space for the pleasure of social life and values which is intend to planned and managed for present and future generation (Huat and Edwards, 1992, Cybriwsky, 1999, Kayden, 2000, Moir, 2002).

Wu and Plantinga (2003) state that public open space is an important part of modern cities as it helps in reducing the stress of people living in society. While, Alexander (1977) described that good social space should be where people feel comfortable and want to interact rather than feel trapped.

According to Jia (2008) public open space displays the social life of a city in the better way, by participating in activities occurs in public open place is an opportunity to learn how people behave, react, work, dress with the people whom with they live and communicate. Most of the time, people participating in public activities in public space become familiar with others as well as sometimes gets new ideas inspired by others of public open space.

Table 1 showing categorisation of public open spaces in India

\begin{tabular}{lll}
\hline S. No. & Category & Types of Public open space \\
\hline 1 & Environment (natural features) & City park \\
& & District park \\
& Community / neighborhood park \\
\hline 2 & Social infrastructure & Sports ground \\
& & Multipurpose ground for exhibitions and fairs \\
\hline 3 & Trade and commerce & $\begin{array}{l}\text { Public open space in Community centres / District } \\
\text { centers (public square / plaza) }\end{array}$ \\
\hline
\end{tabular}




\section{Street markets / bazaars}

Formal / informal markets (handicraft bazaar)

Due to the context, typology of public open spaces is different in every region of the world, even every city has their own typology of public open space. Moreover, the selected site is in Delhi therefore, it is important to identity the typology of public open space in Delhi. Delhi master plan (2010) described that, there is no such categorisation of public open space was constructed, however, as mentioned in table 1 under different categories like environment (natural features), social infrastructure and trade and commerce, public open spaces are defined.

Types of Public open space in India

\begin{tabular}{|c|c|c|c|c|}
\hline $\begin{array}{l}\text { Attractions and } \\
\text { Destinations project for } \\
\text { public spaces approach } \\
\text { based on Whyte (1987) }\end{array}$ & $\begin{array}{l}\text { Gehl architects } \\
\text { approach-Gehl } \\
(2004)\end{array}$ & $\begin{array}{l}\text { True urbanism } \\
\text { approach-making } \\
\text { cities livable - } \\
\text { Lennard (2004) }\end{array}$ & $\begin{array}{l}\text { Design } \\
\text { guidelines for } \\
\text { urban open } \\
\text { space-Marcus } \\
\text { Francis (1998) }\end{array}$ & Derived Factors \\
\hline $\begin{array}{l}\text { Attractions and } \\
\text { Destinations }\end{array}$ & Uses \& activities & $\begin{array}{l}\text { Community } \\
\text { Festivals } \\
\text { Mixed use }\end{array}$ & $\begin{array}{l}\text { Uses \& } \\
\text { activities } \\
\text { Seating } \\
\text { Food an eating } \\
\text { Program }\end{array}$ & Uses \& activities \\
\hline
\end{tabular}

\begin{tabular}{|c|c|c|c|c|}
\hline Access & $\begin{array}{l}\text { Accessibility } \\
\text { Parking } \\
\text { Paving } \\
\text { Traffic Security }\end{array}$ & $\begin{array}{l}\text { Accessibility and } \\
\text { transfer }\end{array}$ & $\begin{array}{l}\text { Access \& } \\
\text { mobility }\end{array}$ & Accessibility \\
\hline $\begin{array}{l}\text { Amenities } \\
\text { Flexible Design }\end{array}$ & $\begin{array}{l}\text { Urban elements } \\
\text { Aesthetic quality }\end{array}$ & $\begin{array}{l}\text { Urban elements } \\
\text { Outdoor cafes \& } \\
\text { restaurants }\end{array}$ & $\begin{array}{l}\text { Urban elements } \\
\text { Amenities }\end{array}$ & $\begin{array}{l}\text { Urban } \\
\text { elements/Ameniti } \\
\text { es }\end{array}$ \\
\hline Image and Identity & $\begin{array}{l}\text { Facades } \\
\text { Access and } \\
\text { mobility } \\
\text { Edge } \\
\text { Views and vistas } \\
\text { Human scale }\end{array}$ & $\begin{array}{l}\text { Image / DNA } \\
\text { Human scale }\end{array}$ & $\begin{array}{l}\text { Visual } \\
\text { Complexity } \\
\text { Size } \\
\text { Boundaries }\end{array}$ & $\begin{array}{l}\text { Visual image and } \\
\text { identity }\end{array}$ \\
\hline Management & Aesthetic quality & & Maintenance & $\begin{array}{l}\text { Maintenance \& } \\
\text { management }\end{array}$ \\
\hline $\begin{array}{l}\text { Reaching Out Like an } \\
\text { Octopus • Inner Square \& } \\
\text { Outer Square }\end{array}$ & $\begin{array}{l}\text { Proximity } \\
\text { and connection }\end{array}$ & $\begin{array}{l}\text { Compact urban } \\
\text { fabric }\end{array}$ & $\begin{array}{l}\text { Circulation } \\
\text { Information and } \\
\text { Signs }\end{array}$ & Linkage \\
\hline Seasonal Strategy & $\begin{array}{l}\text { Climate/Night } \\
\text { situation }\end{array}$ & & $\begin{array}{l}\text { Climate/Night } \\
\text { situation }\end{array}$ & Microclimate \\
\hline
\end{tabular}




\section{Factors of Public open space}

Whyte (1980); Lennard and Lennard (1995); Gehl (Gehl, 1996); Project for public space (2000) stated various factors of Public open space. However, therefore six factors are derived from the above mention studies and consider as the main attributes of this research. The six main factors including access and linkages, uses and activities, urban elements/Amenities, visual image and identity, maintenance and management and microclimate.

\section{Uses and Activities}

Whyte (1980) described uses and activities as one of the essential factors to rejuvenate the Public open space in different time and season. According to Gehl (1996), in public space people are attracted by people and activities are attracted activities. Therefore, it is important to put uses and actives as it generates social interaction and captivates public for longer duration. However, Lennard and Lennard (1995) entitled uses and activities as a community festivals and mixed use. Further, Marcus and Francis (1998) Uses \& activities Seating, Food an eating and programs as the vital factor for generating social interaction in public space.

\section{Access and Linkages}

Whyte (1980); Lennard and Lennard (1995); Gehl (1996); Marcus and Francis (1998) describe, access as a visible approach of the space, while Tibbalds (1992) referred access as a physical and visual reach of a space which affects the user's perception regarding safety and comfort. Taghipour et al. (2015) defined linkages as a connection between spaces, inner and outer circulation.

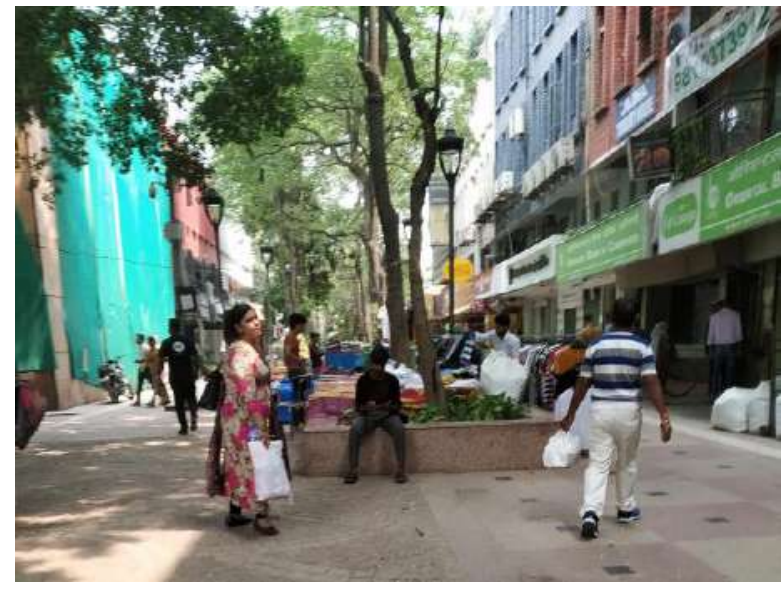

Figure 1: Public open space, New Friends colony, New Delhi

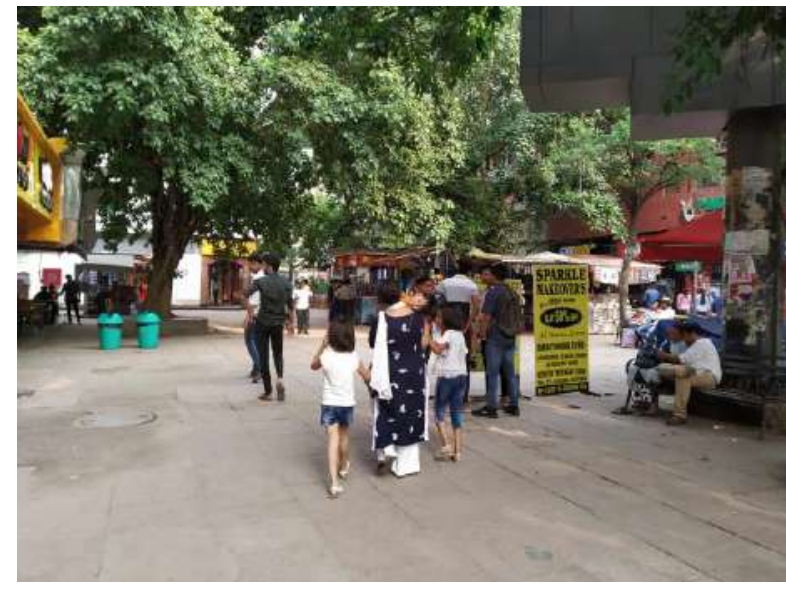

Figure 2: Public open space, Saket, New Delhi

\section{Urban elements/Amenities}

Whyte (1980); Lennard and Lennard (1995); Marcus and Francis (1998); Gehl (2003) considered urban elements and amenities as the major attribute to access the Public open space. Moreover, Carmona et al. (2008) stated that the quality and organization of urban elements is directly related to the quality of public space. While, Whyte (1980) considered, installation of small visually pleasing urban elements like sit outs, installations, cascades attract users. Elements likes sit outs, steps, ponds, monuments, landscape, etc., stimulate people to interact and stay for longer period of time (Kaplan and Kaplan, 1989). 


\section{Visual image and identity}

Whyte (1980) assumed image and identity as a tool to captivate public, while Gehl (1996) assessed urban element and amenities through Facades, Edge, Views and vistas and Human scale. Alike, Lennard and Lennard (1995); Gehl (1996) described image and human scale is a subordinate of visual image and identity. Stephen et al. (1992) describe comfort and image as one of the essential elements of Public open space as it has high impact on people's satisfaction.

\section{Maintenance and management}

Whyte (1980); Marcus and Francis (1998) as a defined maintenance and management as of the requisite aspect of effective Public open space. Rimanova (2010) mentioned safety and maintenance are the two essential factors for the success of Public open space. However, Gehl (1996) mentioned aesthetic quality attracts visitors as it is enhancing the visual appearance of the place.

\section{Microclimate}

Undoubtedly, microclimate affects the user's satisfaction level. Whyte (1980) asserted microclimate as the essential factor of Public open space as it has an undeviating repercussion on user's satisfaction level. Adding to this Stephen et al. (1992), favourable microclimate produces effective physical comfort. Whereas, Carmona et al. (2008) mentioned that at different time of a day i.e. day and night, users perceive place differently. Therefore, public space should have the security provision of both day and night as it directly related to the sense of comfort.

\section{Methods}

\section{Study Area}

For this research, three Public open spaces of south zone, New Delhi has been selected as a case study. The selected site should be distinctive in context yet have similar sizes, from same city. Moreover, the design spaces should be different from each other, in order to get different responses from the users.

Therefore, as per mentioned criteria, the author has taken Public open space of district centre of Saket, Nehru Place and New Friends Colony. District centre of New Delhi includes Hotels, restaurants, commercial areas, offices, etc. Thus, the selected site is surrounded by different land uses which serves to distinctive population.

\section{Data Collection}

This research explores about factors of successful public open space. The methodology of conducting research is held through questionnaire survey. This gives an idea that which factor is important for users as well as their satisfaction about different design spaces. Prior to survey, a pilot study comprises of 19 samples has been done in order to establish the validity of the questionnaire.

\section{Sample size}

The select site areas have a finite population of 2,733,752 (2011 census). The selection of sample size is based on Israel (1992) sample formula for finite population. Therefore, according Israel (1992) the calculated sample size is 400 persons for population more than 100,000 by taking _ $+5 \%$ precision level. For research analysis, confirmatory factor analysis has been adopted. According to Stallings (1975); Hair. et al. (2010), the ratio of 
items and respondents should be 1:10, moreover, this research includes 27 questionnaires under four different factors. Therefore, the sample size be minimum 290.

\section{Questionnaire Design}

The purpose of questionnaire is to explore the user's experience regarding different factors of Indian public open spaces. The design of questionnaire is based on the 'Likert scale' in order to get the most reliable outcomes. The construct of questions is divided into six parts including six attributes of Public open space which constitute 27 items/attributes. Moreover, in each construct, similar questions were asked in order to check the reliability of answers (Likert, 1932). Further, the questionnaires are designed to obtained the satisfaction level of the users as it defines their needs regarding Public open space.

\section{Data Analysis}

For data collection, 30 questions are designed under six different constructs in order to find out the most preferred factor by users. The data analysis has been performed into three stages. Primarily, Cronbach's alpha has been conducted in order to check the internal consistency of a construct. Moreover, the value of Cronbach's alpha more than 0.7 is consider as acceptable (Cronbach, 1951). Thus, all the construct is having acceptable alpha value as shown in Table 3 .

Secondly, in order to validate the item of each construct, exploratory factor analysis has been done. Principal component analysis with Varimax rotation has been employed as a preliminary tool in order to validate the selected items. Items having factor loading less than 0.5 are removed from the construct (Hurley et al., 1997). Therefore, 27 items are selected whereas three items have been deleted from the construct as it is unable to meet the required factor loading. In the end, confirmatory factor analysis has been performed to find out the correlation between each construct as well as standardised factor loading of each item and construct in order to examine the most essential construct of Public open space in Indian context.

Table 3 Table showing exploratory factor analysis of attributes of Public open space

\begin{tabular}{llllc}
\hline Construct & $\begin{array}{l}\text { No. } \\
\text { of } \\
\text { items }\end{array}$ & Indicators & $\begin{array}{l}\text { Factor } \\
\text { loading }\end{array}$ & $\begin{array}{l}\text { Cronbach } \\
\text { 's Alpha }\end{array}$ \\
\hline $\begin{array}{l}\text { Access and } \\
\text { linkages }\end{array}$ & 4 & Entrance is good & 0.810 & 0.909 \\
& & Clear entry and exit & 0.810 & \\
& & Easy to get parking space & 0.779 & \\
& Walkable distance from bus, metro to public open space & 0.796 & \\
\hline $\begin{array}{l}\text { Uses and } \\
\text { activities }\end{array}$ & 5 & Spaces are attractive & 0.819 & 0.928 \\
& & Activities are sufficient to spend time & 0.843 & \\
& & Diversity in activities & 0.846 & \\
& & Activities for less abled, senior citizens & 0.882 & \\
\hline Urban & Sufficient area for shopping, relaxing & 0.850 & \\
elements/Ame & 6 & Diversitylin physical form & 0.809 & 0.937 \\
\hline
\end{tabular}




\begin{tabular}{lllll} 
nities & Toilets, drink water and first aid available & 0.836 & \\
& & Street furniture and street lightings are available & 0.851 & \\
& & Water fountain/Statues/sculpture are attractive & 0.839 & \\
& & Sufficient area for shopping/relaxing & 0.841 & \\
\hline \multirow{2}{*}{$\begin{array}{l}\text { Visual image } \\
\text { and identity }\end{array}$} & & Spaces are captivating & 0.836 & 0.917 \\
& & Attractive landscape and open area & 0.816 & \\
\hline Maintenance & Urban elements are in harmony & 0.840 & \\
\&management & 4 & Visually appealing designed spaces & 0.844 & \\
& & security cameras are properly installed & 0.631 & \\
& & Proper Night Lighting & 0.628 & \\
& & Spaces are clean & 0.633 & 0.844 \\
\hline Microclimate & 4 & No noise/smell in surrounding & 0.603 & \\
& Shade protect the play areas from climatic condition & 0.508 & \\
& & Sitting with proper shades (temporary/trees & 0.617 & \multirow{2}{*}{0.842} \\
& Green areas are provided for shade and relaxing & 0.610 & \\
\hline
\end{tabular}

\section{Confirmatory factor analysis}

Confirmatory factor analysis is a subset of structural equation modelling which is intended to test the hypothesis of designed model and ensure model fit data which involve determining existence of relationship between latent, observed, unobserved variables and constructs (Child, 1990, Byrne, 2016). This confirmatory factor analysis model contains exogenous (independent) and endogenous (dependent) variable comprises indirect and direct effects of one variable on other.

\section{Validity and Reliability}

In order to check the model fitness, there are few indices which testify the goodness of fitness of a model. This includes CMIN (likelihood ratio of chi square), GFI (goodness of fit index), AGFI (Adjusted Goodness-of-Fit Index), RMSEA (Root Mean Square Error of Approximation), RMR (Root Mean Square Residual). According to Joreskog and Sorbom (1986), the value of CMIN should be less than 5, while Bagozzi and Yi (1988); Anderson and Gerbing (1988) recommended values of GFI, AGFI $\geq 0.90$. Further, (Browne and Cudeck, 1992) commend values of RMSEA $\leq 0.08$ and RMR $\leq 0.1$. Furthermore, Rasidi et al. (2012) mentioned that RMSEA depends on degree of freedom as well as indicates the badness of fit index. 


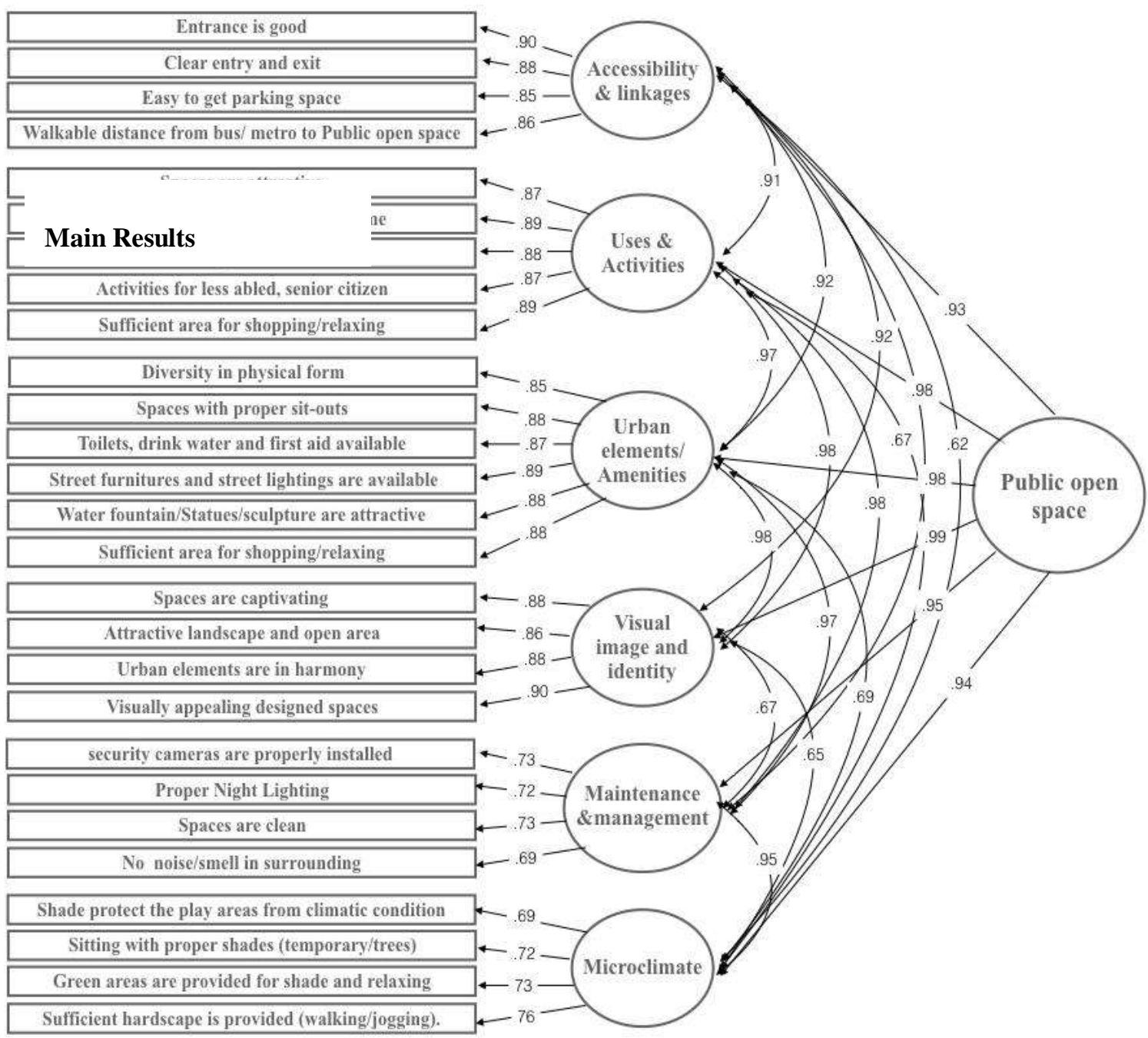

Main Res

Figure 3 showing results of confirmatory factor analysis of Public open space factors 
Table 4 showing model fit indices of confirmatory factor analysis of Public open space attributes

\begin{tabular}{llllll}
\hline $\begin{array}{l}\text { Goodness of fit } \\
\text { measures }\end{array}$ & $\begin{array}{l}\chi 2 \text { test } \\
\text { statistics/df }\end{array}$ & GFI & AGFI & RMSEA & RMR \\
\hline Recommended value & $\leq 3.00 \mathrm{a}$ & $\geq 0.90 \mathrm{~b}$ & $\geq 0.90 \mathrm{~b}$ & $\leq 0.08 \mathrm{c}$ & $\leq 0.1 \mathrm{c}$ \\
\hline Structural model & 1.574 & 0.909 & $0 . .892$ & 0.037 & 0.080 \\
\hline
\end{tabular}

Note: $\mathrm{N}=461$; GFI = Goodness-of-Fit Index; AGFI = Adjusted Goodness-of-Fit Index; CFI = Comparative Fit Index;

NFI = Normed Fit Index; RMSEA = Root Mean Square Error of Approximation; RMR = Root Mean Square Residual Source: a (Jöreskog and Sörbom 1986), b (Bagozzi and Yi 1988), b (Anderson and Gerbing 1988), c (Browne and Cudeck 1993)

As already mentioned, that the results are achieved in three steps. First Cronbach's alpha value has been done in order to check the reliability of answers followed by the exploratory factor analysis for checking the factor loading of each item and then confirmatory factor analysis has been performed which examine the correlation between each construct. Through table 3, it can see that all the constructs are having excellent alpha value, comprising access and linkages (0.909), uses and activities (0.928), urban elements/Amenities (0.937), visual image and identity (0.917), maintenance and management (0.844) and microclimate (0.842).

The results of exploratory factor analysis reveal that 27 items are above the required value of 0.5 while two from microclimate and one from Maintenance \& management has been deleted as it is having lower factor loading value. The results demonstrate that the items of accessibility and linkages construct ranging factor loading between 0.810 to 0.779 , while in users and activities construct mostly factor loading are between 0.819 to 0.850 . Moreover, urban elements/Amenities factor loading is between 0.808 to 0.851 , while, visual image and identity is in a range of 0.816 to 0.844 . Further, maintenance and management factor loading ranges between 0.603 and 0.633 , whereas microclimate factor loading is between 0.508-0.622 (table 3).

\section{Validity and Reliability of factors of Public open space model}

To analyses the validity of model, confirmatory factor analysis has been performed. The confirmatory factor analysis model reveals that all the goodness of fit indices are under recommended value shown in table 4. The value of $\mathrm{CMIN} / \mathrm{df}=1.574, \mathrm{GFI}=.909, \mathrm{AGFI}=.892, \mathrm{RMSEA}=0.037$ and $\mathrm{RMR}=0.080$, which signifies that all the values of indices are under recommended values and eventually proves the model is fit.

\section{Relation between variables}

The result of correlation between factors has been performed using confirmatory factor analysis shown in figure 2. The outcomes reveal that all the factors have strong correlation between with other which confirms that factors are fits to Indian context. The relation of accessibility and linkages with uses and activities is 0.91 ; Urban elements/Amenities is 0.92 and with Visual image and identity is 0.92 ; with Maintenance \& management is 0.98 and with Microclimate is 0.62 . While, relation of uses and activities with Urban elements/Amenities is 0.97 ; with Visual image and identity is 0.98 ; with Maintenance \& management is 0.67 and with Microclimate is 0.98. Moreover, relation of Urban elements/Amenities with Visual image and identity is 0.98; with Maintenance \& management is 0.97 and with Microclimate is 0.69 . However, relation of Visual image and identity with 
Maintenance \& management is 0.67 and with Microclimate is 0.65 whereas correlation between Maintenance \& management Microclimate is 0.95

\section{Discussion}

The results demonstrate that there is a high correlation between all the factors which means that all the factors are highly connected with Indian context. Though figure 2, it can be seen that uses and activities with Urban elements/Amenities and Visual image and identity are highly correlated. Therefore, will designing, these factors should complement each other as well as should give equal emphasis.

Adding to this, relation of accessibility and linkages with uses and activities, Urban elements/Amenities, Visual image and identity and Maintenance \& management is also demonstrating significantly high relation. This is what Lynch (1981) defined that paths are the vital element in order to define image of the space. Thus, accessibility and linkages should be considered as one of the significant factors while designing.

On the other hand, visual image and identity showing highest standardised factor loading of 0.99 followed by Urban elements/Amenities and uses and activities having 0.98 value. Thus, these factors play pivotal role in Indian Public open space.

\section{Conclusion}

In conclusion, the research confirms that, to achieve successful Public open space in Indian context, accessibility and linkages, uses and activities, Urban elements/Amenities, Visual image and identity, Maintenance \& management and Microclimate are the six vital factors. Visual image and identity is one of the significant factor of Indian Public open space, followed by the Urban elements/Amenities and uses and activities, while Maintenance \& management and microclimate are equally important. However, standardised factor loading of accessibility and linkages elucidates that considered importance should also be given for uplifting the effectiveness in Public open space. Thus, the above given factors are fits to Indian context and should considered as successful factors of Public open space while designing.

\section{References}

ALEXANDER, C. 1977. A Pattern Language, Oxford, United Kingdom, Oxford University Press.

ANCELL, S. \& THOMPSON-FAWCETT, M. 2008. The Social Sustainability of Medium Density Housing: A Conceptual Model and Christchurch Case Study. Housing Studies, 23, 423-441.

ANDERSON, J. C. \& GERBING, D. W. 1988. Structural Equation Modeling in Practice: A Review and Recommended Two-Step Approach. Psychological Bulletin, 103, 411-423.

BAGOZZI, R. P. \& YI, Y. 1988. On the evaluation of structural equation models. Journal of the Academy of Marketing Science, 16, 74-94.

BROWNE, M. W. \& CUDECK, R. 1992. Alternative Ways of Assessing Model Fit. Sage Publications, 21, 230258.

BYRNE, B. M. 2016. Structural Equation Modeling With AMOS: Basic Concepts, Applications, and Programming, Nw York / East Sussex, Routledge/Taylor \& Francis.

CHILD, D. 1990. The essentials of factor analysis, London, Cassel Educational Limited.

CRONBACH, L. 1951. Coefficient Alpha and the Internal Structure of Tests. Psychometrika, 297-334.

CYBRIWSKY, R. 1999. Changing patterns of urban public space-observations and assessments from the Tokyo and New York metropolitan areas. Journal of Cities, 16, 223-231.

DEBRA EFROYMSON, T. T. K. T. H., PHAM THU HA 2009. Public Spaces: How They Humanize Cities, Dhaka, HealthBridge - WBB Trust. 
GEHL, J. 1996. Life Between Buildings: Using Public Space, Copenhagen, Danish Architectural Press and the Royal Danish Academy of Fine Arts, School of Architecture.

GIDDINGS, B., CHARLTON, J. \& HORNE, M. 2011. PUBLIC SQUARES IN EUROPEAN CITY CENTRES. Urban Design International, 16, 202-212.

HAIR., J. F., BLACK, W. C., BABIN, B. J. \& ANDERSON, R. E. 2010. Multivariate data analysis, New York, Pearson Prentice Hall.

HAJJARI, M. 2009. Improving urban life through urban public spaces: a comparison between Iranian and Australian cases. International Graduate Research Conference: Sustainable Cities for the Future. Melbourne \& Brisbane.

HUAT, C. B. \& EDWARDS, N. 1992. Public Space: Design, Use and Management, Singapore, Singapore University Press.

HUME, G. 2009. Cultural planning for creative communities, St. Thomas, Canada, Municipal World.

HURLEY, A. E., SCANDURA, T., SCHRIESHEIM, C., BRANNICK, M. T., SEERS, A., VANDENBERG, R. J. \& WILLIAMS, L. J. 1997. Exploratory and confirmatory factor analysis: Guidelines, issues and alternatives. Journal of Organizational Behavior, 18, 667-683.

ISRAEL, G. D. 1992. Determining Sample Size.

JAN GEHL, L. G. 2003. New City Spaces, Copenhagen, Danish Architectural Press.

JIA, Z. 2008. Creating an attractive public space for the citizens. Phd, Blekinge Institute of Technology.

JÖRESKOG, K. G. \& SÖRBOM, D. 1986. LISREL VI: Analysis of linear structural relationships by maximum likelihood and least square methods, Mooresville, Ind, Scientific Software.

KAPLAN, R. \& KAPLAN, S. 1989. The Experience of Nature: A Psychological Perspective, Cambridge., Cambridge University Press.

KAYDEN, J. S. 2000. Privately Owned Public Space: the New York City Experience, New York, John Wiley.

KOSTOF, S. 1992. The City Assembled: The Elements of Urban Form Through History, Little Brown.

LIKERT, R. 1932. A Technique for the Measurement of Attitudes. Archives of Psychology, 22, 1-55.

LYNCH, K. 1981. The Image of the City, Cambridge, MIT Press.

MARCUS, C. C. \& FRANCIS, C. 1998. People Place: Design guidelines for urban open space, New, ohn Wiley $\&$ Sons, Inc.

MATTHEW CARMONA, HAMMOND, L. \& MAGALHÃES, C. D. 2008. Public space : the management dimension / Matthew Carmona, Claudio de Magalhães, Leo Hammond, London, Routledge.

MOIR, N. 2002. The Commercialisation of Open Space and Street Life in Central District, Hong Kong, Civic Exchange.

PPS. 2000. How to Turn a Place Around: A Handbook of Creating Successful Public [Online]. New York, U.S.A.: Project for Public Spaces. Available: https://www.pps.org/article/grplacefeat [Accessed].

RASIDI, M. H., JAMIRSAH, N. \& SAID, I. 2012. Urban Green Space Design Affects Urban Residents' Social Interaction. ASIA Pacific International Conference on Environment-Behaviour Studies. Giza, Egypt: Elsevier.

ŘÍMANOVA, M. 2010. Research: towards socially attractive city squares. M.sc, Wageningen University and Research Centre.

STALLINGS, E. S. 1975. Multivariate analysis: The need for data, and other problems. British Journal of Psychiatry, 237-240.

STEPHEN, C., RIVLIN, L. G., FRANCIS, M. \& STONE, A. M. 1992. Public Space, New York, Cambridge University Press.

SUCKER, K. 2010. Istanbul and the Heritage of the European City. Journal of Science- Future of Lithuania, 2, $31-37$. 
SUZANNE H. CROWHURST LENNARD \& LENNARD, H. L. 1995. Livable cities observed: a source book of images and ideas for city officials, community leaders, architects, planners and all other committed to making their cities livable, Carmel, CA, Gondolier Press.

TAGHIPOUR, M., SOLTANZADEH, H. \& AFKAN, K. B. 2015. The Role of Spatial Organization in Social Interaction of Residents of Residential Complexes (Case Study: Two Residential Complexes in Shiraz, Iran). Research Journal of Applied Sciences, Engineering and Technology, 10, 86-93.

TIBBALDS, F. 1992. Making People Friendly Towns, Harlow : Longman.

TRUONG, V. 2008. Sydney City's Public Open Spaces. unpublished masters thesis, University of New South Wales,.

WHYTE, W. H. 1980. The Social Life of Small Urban Spaces, New York, Project for Public Spaces.

WU, J. J. \& PLANTINGA, A. J. 2003. The influence of public open space on urban spatial structure. Journal of Environmental Economics and Management, 46, 288-309. 